\title{
Tecnología robótica en cirugía oral y maxilofacial
}

\author{
Robotic technology in oral and maxillofacial surgery
}

\section{J.A. Hueto Madrid}

Resumen: La utilización de robots en cirugía como ayudantes o como cirujanos despierta interés desde hace décadas. Sus características de precisión, incansabilidad y muchas otras ventajas auguran a esta tecnología un papel destacado en la cirugía maxilofacial del futuro. No obstante, las experiencias en nuestro campo y en otras especialidades quirúrgicas han puesto de manifiesto la falta de madurez de la tecnología robótica para incorporarse a corto plazo a los quirófanos. La introducción de tecnologías para una mayor miniaturización, su actuación cooperativa y una mejor interacción con el medio pueden aportar las características que necesitan para ser útiles y definitivamente incorporarse a nuestra actividad.

Palabras clave: Robótica; Nuevas tecnologías; Cirugía oral maxilofacial.

Recibido: 29.10 .07

Aceptado: 31.11 .07

\begin{abstract}
The use of robots in surgery as operating room assistants or as surgical agents has attracted interest for decades. Their accuracy, resistance to fatigue and many other features augur a prominent role of this technology in maxillofacial surgery in the future. Nevertheless, experience in this field and other surgical specialities has shown that robotic technology is not yet mature enough to be used routinely in operating rooms. The introduction of new technologies to improve miniaturization, cooperative work, and better interactive behavior may endow robots with the necessary features to make them useful enough to include them in our surgical activities.
\end{abstract}

Key words: Robots; New technology; Oral maxillofacial surgery

\footnotetext{
Médico Adjunto.

Servicio de Cirugía Oral y Maxilofacial.

Director del Grupo de Investigación en Robótica y Cirugía Craneofacial.

Hospital Universitario Vall d’Hebrón, Barcelona, España
}

\section{Correspondencia:}

J.A. Hueto Madrid

Servicio de Cirugía Oral y Maxilofacial

Hospital Universitario Vall d'Hebron.

Paseo Vall d'Hebron, 119

08006 Barcelona, España 


\section{Introducción}

Se atribuye a Aristóteles en el siglo IV ac. el concepto de la automatización. En aquellos tiempos escribió sus pensamientos sobre como mejorar los autómatas de la época: "...si cada instrumento pudiera hacer su propio trabajo, obedeciendo y anticipando las órdenes ... si la lanzadera supiera tejer, si la púa supiera tocar la lira sin la mano que las guiara, los amos no necesitarían tener siervos". ${ }^{1}$ Lo que Aristóteles proponía iba más allá de los simples autómatas, que repiten mecánicamente los movimientos para los que han sido programados. Introdujo la necesidad de una cierta inteligencia detrás de los movimientos de los dispositivos, dotándolos de una capacidad para tomar

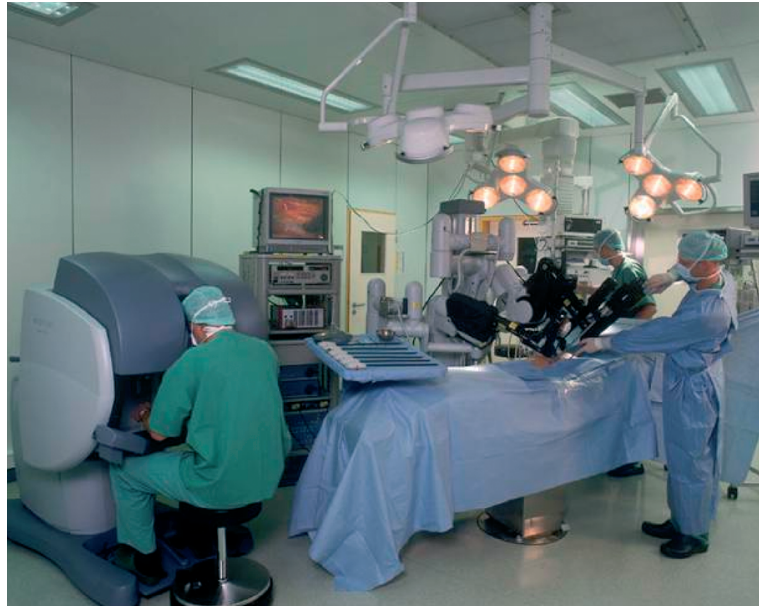

Figura 1. Sistema Da Vinci para laparoscopia. Reproducido con permiso de Intuitive Surgical Inc.

Figure 1. Da Vinci laparoscopy system. Reproduction authorized by Intuitive Surgical, Inc.

\section{Introduction}

The concept of automatization is attributed to Aristotle, fourth century AD. Aristotle wrote about how he thoughts the robots of his time could be improved: "...if each instrument could do its own work, obeying and anticipating orders... if the loom's shuttle knew how to weave, if the pick knew how to stroke the lyre without a hand to guide it, then masters would have no need for servants".? What Aristotle was proposing went beyond simple robots, which mechanically repeat the movements that they have decisiones sobre la marcha. Para que un dispositivo pueda tomar decisiones sobre sus movimientos, deduciendo la acción más conveniente, es necesario un cierto juicio o inteligencia y un cierto grado de percepción del entorno.

Los autómatas ya aparecieron en la antigua Grecia, aunque con poca aplicabilidad práctica y se usaban más como divertimento que como herramientas útiles. El único autómata que realmente tuvo aplicación práctica fue el reloj.

El robot concebido como autómata tiene muchas limitaciones en cirugía, debido al cambiante entorno de trabajo y combinación de estructuras elásticas, flexibles, fluidas, viscosas y sólidas que componen los seres vivos. Estos problemas son los que hacen difícil trasladar al quirófano a los eficientes robots industriales, que de forma económica e incansable, con rapidez y precisión, son capaces de pintar un coche o montar un televisor. Los requerimientos para los ingenieros son altísimos, pues en la práctica se les pide que reproduzcan y mejoren de forma robótica las prestaciones de un ser humano.

Los primeros robots empleados en cirugía actuaban como autómatas, ejecutando rigurosamente su programación o los movimientos de un operador del sistema, sin interacción con el medio y sin tomar decisiones por sí mismos.

Las experiencias clínicas se iniciaron a finales de los 80 en cirugía gastrointestinal, urología y cirugía cardiaca. La mayoría de estos sistemas se han empleado en cirugía endoscópica u otros procedimientos de cirugía mínimamente invasiva. ${ }^{2-8}$

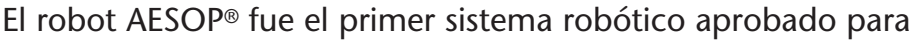
cirugía por la FDA en 1994. Este robot actuaba llevando la cámara en cirugía laparoscópica. Una versión posterior aprobada en 2000 incorporaba un sistema de reconocimiento de voz y actuaba frente a órdenes orales del cirujano.

El sistema ZEUS $^{\circledR}$ fue desarrollado en Europa e introducido en clínica en 1998.

El sistema Da Vinci ${ }^{\circledR}$, compuesto por dos brazos robóticos, publicó sus primeras experiencias en 1995 (Fig. 1). A este sistema corresponde el mérito de las primeras experiencias en cirugía cardiaca: reparaciones valvulares y cirugía de "by pass" de las arterias coronarias. ${ }^{18}$ been programmed to do. He envisioned the need for some sort of intelligence that would govern the movements of the devices, endowing them with capacity to make on-the-spot decisions.

Some sort of judgment or intelligence and a certain degree of perception of the surroundings are necessary for a device to make decisions about its movements by deducing the most advisable action.

Robots existed in ancient Greece, but they had little practical applicability and were used more as for entertainment than as tools. The only robot with a real practical application was the clock.

Automaton type robots have many limitations in surgery due to the variability of the work setting and the combination of elastic, flexible, fluid, viscous, and solid structures that make up living beings. These problems make it difficult to replicate the efficiency of industrial robots, which work economically and untiringly, quickly and precisely, equally capable of painting a car or assembling a television set, in the operating room.

The engineering specifications are extremely high because, in practice, robots are expected to work as well as or better than human beings.

The first robots used in surgery acted as automatons, rigorously executing their programming or the movements of the system operator without interacting with surroundings and making decisions autonomously.

Clinical experiences began to accumulate in the late 1980 s in gastrointestinal surgery, urology, and cardiac surgery. Most of these systems have been used in endoscopic surgery or other minimally invasive surgical procedures. ${ }^{2-8}$

AESOP ${ }^{\text {Robot }}$ was the first robotic system approved for surgical use by the FDA in 1994. This robot bears the camera in laparoscopic surgery. A later version approved in 2000 had a voice recognition system that acted in response to the surgeon's verbal orders. 
Las ventajas de los robots en cirugía todavía no están claras. El alto coste de los sistemas y la prolongación de los tiempos quirúrgicos no se ven compensados por su mayor precisión y predictibilidad de los tratamientos. Probablemente la estrategia seguida hasta ahora en su introducción, intentando sustituir la intervención humana en los procedimientos, no haya sido la más adecuada. El mayor campo que a nuestro entender abre la introducción de los robots es el desarrollo de nuevas técnicas, imposibles de realizar "a mano". Estamos hablando de técnicas mínimamente invasivas, con miniincisiones o endoscópicas. Técnicas que impliquen muy alta precisión (cirugía CAD-CAM) como podrían ser la implantología y las grandes resecciones craneofaciales podrían ser efectuadas con la ayuda de robots.

La explosión en la utilización de robots en medicina y cirugía se producirá en el momento en que sea posible su miniaturización intensiva para poder utilizar "clusters" (racimos o enjambres) de minirobots que actúen de forma coordinada con inteligencia propia orientada a acciones concretas.

La miniaturización de los robots abrirá nuevas opciones terapéuticas como la robotización de los distractores: distractores completamente sumergidos, con cierta inteligencia y la posibilidad de recibir instrucciones del cirujano para modificar sus vectores. Otra posibilidad de introducción sería la automatización de procesos repetitivos, como las suturas microquirúrgicas, suturas cutáneas, colocación de placas y tornillos de osteosíntesis, etc.

Los robots en medicina pueden adoptar diferentes configuraciones según las acciones para las que están diseñados: ${ }^{9}$

- Robots asistentes: son máquinas que sustituyen a un asistente en la cirugía. Pertenecerían a este tipo los robots que se emplean en laparoscopia para separar y llevar la cámara de video.

- Sirvientes robóticos: son sistemas dedicados a ayudar a pacientes minusválidos a efectuar tareas comunes como la alimentación, la toma de los medicamentos, movilidad, etc.

- Prótesis robotizadas: son dispositivos que conectados al paciente sustituyen la acción de los miembros o extremidades perdidas

- Simuladores: sistemas robóticos que permiten simular intervenciones quirúrgicas para aprendizaje y perfeccionamiento. Se han desarrollado sobre todo para cirugía laparoscópica. ${ }^{10}$ Dentro de este apartado podríamos incluir robots diseñados para reproducir la biomecánica del ser humano: reproducción de los movimientos mandibulares,11-12 del pie, de la muñeca, etc.

- Robots para diagnóstico: se emplean en ecografía y otras técnicas radiológicas para mejorar la precisión. Existen también robots localizadores del pulso para punción arterial.

- Robots pasivos: empleados en sistemas de navegación quirúrgica.

- Sistemas CAD-CAM: empleados en implantología para la construcción de férulas de posicionamiento.

Desde el punto de vista de la cirugía, los robots podemos dividirlos en tres grupos:

- Telemanipuladores: son robots esclavos, que carecen de toda iniciativa. Se limitan a reproducir con precisión los movimientos que el cirujano ejecuta en tiempo real, desde una consola, en la que puede ver la imagen del campo operatorio. Esta con-
ZEUS ${ }^{\circledR}$ System was developed in Europe and introduced into clinical practice in 1998.

The first experiences with the Da Vinci ${ }^{\circledR}$ system, consisting of two robotic arms, were published in 1995 (Fig. 1). This system was used in the first robotic experiences in cardiac surgery: valvular repair and coronary artery bypass surgery. ${ }^{18}$

The advantages of robots in surgery still are not clear. The high cost of the systems and prolongation of surgical times are not recompensated with enhanced treatment precision and predictability. The strategy for introducing the systems probably was inappropriate because they were presented as a replacement for the intervention of humans in procedures. As we understand, the most important area opened by the introduction of robots is in the development of new techniques that cannot be performed by hand. For instance, minimally invasive techniques with tiny incisions or endoscopic techniques. Techniques requiring extremely high precision (CADCAM surgery), such as implantology and large craniofacial resections, could be performed with the help of robots.

The use of robots in medicine and surgery will expand rapidly when intensive miniaturization becomes possible, which will make it possible to use "clusters" of minirobots that act together, guided by their own intelligence, to perform specific actions.

Robot miniaturization will open the way to new therapeutic options, such as distractor robotization. Intelligent distractors that are completely submerged could respond to instructions from the surgeon to modify their vectors. Another possibility for using robots could be to automate repetitive processes, such as the placement of microsurgical sutures, skin sutures, osteosynthesis plates and screws, etc.

Robots in medicine can adopt different configurations depending on the function for which they are designed:9

- Assistant robots: machines that substitute a surgical assistant. The robots used in laparoscopy to separate and carry the video camera are of this type.

- Robotic servants: systems dedicated to helping disabled patients perform common tasks like feeding, taking medications, moving, and others.

- Robotic prostheses: devices connected to the patient that replace the action of lost limbs or extremities.

- Simulators: robotic systems used to simulate surgical operations for training and practice. Simulators have been developed especially for laparoscopic surgery. ${ }^{10}$ They include robots designed to reproduce human biomechanics: mandibular, 11,12 foot, wrist, and other movements.

- Diagnostic robots: used in ultrasonography and other radiological techniques to enhance precision. There are also pulse-locating robots for arterial puncture.

- Passive robots: used in surgical navigation systems.

- CAD CAM systems: used in implantology to construct positioning splints.

Robots can be divided into three surgical groups:

- Telemanipulators: slave robots without any initiative. Telemanipulators are limited to accurately reproducing 
sola puede estar junto al paciente en el mismo quirófano o a distancia (telecirugía).

- Robots preprogramados: el robot ejecuta una serie de movimientos y acciones que han sido previamente programados sobre datos preoperatorios del paciente.

- Robots preprogramados inteligentes: el robot es programado para ejecutar una tarea, pero puede modificar los parámetros de su ejecución en función de cambios en las condiciones de la intervención: posición del paciente, obstáculos, temperatura, etc. ¿Qué cualidades debe presentar un sistema robótico para ser útil en cirugía? Las vamos a resumir en estos cuatro parámetros:

- Inteligencia. Cuando hablamos de dotar al robot de "inteligencia" nos referimos a su capacidad de interpretar las órdenes del cirujano y de tomar ciertas decisiones. Por ejemplo: al ordenar al robot "Separa la lengua!", el robot debe considerar multitud de parámetros e integrar toda la información de su entorno: entender la orden, determinar su propia posición en el espacio, identificar visualmente la lengua y determinar su posición, determinar todos los movimientos necesarios para la ejecución, mover el instrumento a través de una zona segura sin lesionar al paciente ni interferir al cirujano, aplicar una presión suficiente, etc.

- Percepción. Para poder actuar de forma eficiente, es imprescindible dotar al robot de la capacidad de percibir su entorno. Los parámetros más importantes son su propia posición, su posición relativa al paciente, al cirujano u otros elementos y la detección de posibles obstáculos. Los "sentidos" básicos del robot deberán ser los humanos: vista, propiocepción, tacto y temperatura. Sin embargo, pueden ampliarse más allá de nuestros propias capacidades (percepción o realidad aumentada): $\mathrm{pH}$, infrarrojos, rayos $\mathrm{X}$, ondas electromagnéticas (radar), espectroscopia, ultrasonidos, etc. ${ }^{13}$

- Flexibilidad. Uno de los inconvenientes de muchos sistemas robóticos actuales es que han sido diseñados para un procedimiento quirúrgico en particular. Difícilmente pueden ser adaptados para otros procedimientos distintos para los que han sido diseñados. El volumen de los equipos y sus requerimientos de espacio e infraestructura hacen que en muchas ocasiones el quirófano deba ser construido a su alrededor y no sean transportables.

- Seguridad. Además de los requerimientos técnicos que precisa cualquier dispositivo de electromedicina en su utilización clínica, los robots deben cumplir unos requisitos adicionales de seguridad. Deben poder detenerse y retirarse del campo con rapidez ante una emergencia. Deben diseñarse de tal forma que no puedan lesionar al paciente ni al personal del quirófano. No deben interferir con los dispositivos de soporte vital y anestesia. Deben poder ser esterilizados completamente por los sistemas convencionales (calor, gases, etc.).

\section{Robots en Cirugía Oral y Maxilofacial}

Las experiencias con robots en cirugía oral y maxilofacial son anecdóticas. Existen muy pocas experiencias en nuestra especialidad, la mayor parte de ellas centradas en cirugía ósea, por ser el the surgeon's real-time movements from a console in which an image of the operating field is viewed. The console may be located beside the patient in the same operating room or some distance away (telesurgery).

- Preprogrammed robots: these robots execute a series of movements and actions that have been programmed previously using the patient's preoperative data.

- Preprogrammed intelligent robots: these robots are programmed to execute a task, but they can modify the parameters of execution in response to changes in the intervention conditions, such as patient position, obstacles, temperature, and others.

What qualities must a robotic system have to be useful in surgery? We can summarize these qualities in four parameters:

- Intelligence: When we speak of a robot endowed with "intelligence, "we are referring to its capacity to interpret the surgeon's orders and to make certain decisions. For example, when we order a robot to "separate the tongue," the robot has to process a series of parameters and integrate all the information about its surroundings: understand the order, determine its spatial position, identify the tongue visually and determine its position, determine all necessary movements for execution, move the instrument through a safe zone without injuring the patient or interfering with the surgeon, apply sufficient pressure, etc.

- Perception: The robot has to be able to perceive its surroundings to act efficiently. The most important parameters are the robot's position, its position relative to the patient, surgeon or other elements, and the detection of possible obstacles. The robot's basic "senses" should be human senses: vision, proprioception, touch, and temperature. The perception of robots can, however, be expanded beyond our own capacities (enhanced perception or reality): $\mathrm{pH}$, infrared, X-rays, electromagnetic waves (radar), spectroscopy, ultrasound, and others. ${ }^{13}$

- Flexibility: One of the disadvantages of many existing robotic systems is that they have been designed for specific surgical procedures. It is difficult to adapt them for procedures different from those for which they have been designed. Because of the volume of the equipment and its spatial and infrastructure requirements, the operating room often must be constructed around the equipment, which is not transportable.

- Safety: Aside from the technical requirements of any electromedical device for clinical use, robots must satisfy additional safety requirements. They must be capable of stopping and withdrawing from the field quickly if an emergency arises. They must be designed so that they cannot injure the patient or operating room personnel. They must not interfere with life support devices and anesthesia. They have to be fully sterilizable using conventional systems (heat, gases, and other). 
tejido de mas fiel reproductibilidad en el TAC. La mayoría de prototipos publicados no han llegado a ser usados en un quirófano y con un paciente real. ${ }^{18}$ Una posible explicación es que la mayor parte de sistemas comerciales se han venido desarrollando para cirugía endoscópica, cuyas aplicaciones son limitadas todavía en nuestra especialidad. El coste de los equipos y nuestro limitado catálogo de procedimientos mínimamente invasivos dificultan el desarrollo de esta tecnología. Con la introducción de la endoscopia en procedimientos de traumatología facial, articulación temporomandibular y glándulas salivales se abre la posibilidad de aprovechar estas herramientas en nuestro campo. La AAOMS, en el AAOMS Research Summit celebrado en Chicago en 2005, menciona las tecnologías robóticas, junto con la cirugía mínimamente invasiva, la nanotecnología y la miniaturización como las tecnologías emergentes con más posibilidades en nuestra especialidad.

En Europa existe un gran interés en este campo, aunque los esfuerzos investigadores se han desplazado a las técnicas de navegación. Existen prototipos de cirugía maxilofacial con robots en Alemania, Austria y Francia. ${ }^{17}$

\section{Experiencias en España}

En España, el grupo del Hospital Vall d'Hebrón y la Universitat Politècnica de Catalunya diseñó un sistema robotizado para osteotomías. El sistema incorporaba un brazo robótico que controlaba los movimientos de una pieza de mano con fresa de espiga o Lindeman (Fig. 2).

El sistema incorpora cuatro módulos diferentes. El primero es el módulo de imagen, que se ocupa de la obtención y manipulación de la imagen de tomografía computarizada, generando un modelo tridimensional a partir de los ficheros DICOM del tomógrafo (Fig. 3).

El segundo módulo es el de coordenadas. Se ocupa en tiempo real de coordinar la posición en el espacio del modelo virtual con la realidad. Para ello se emplea la tecnología de visión por computador. El paciente real tiene adheridas en superficie unas dianas y el ordenador ve el objeto real mediante tres cámaras. Con algo-

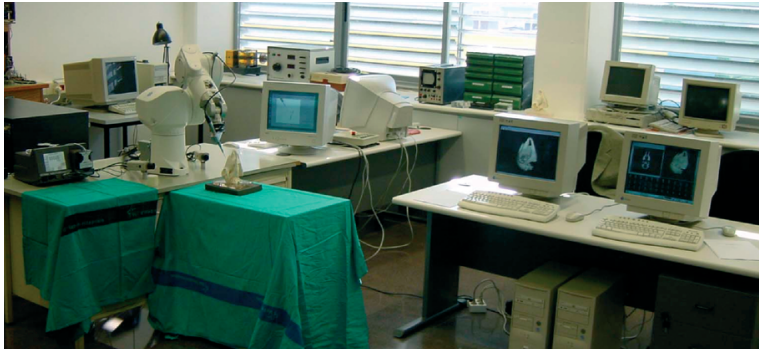

Figura 2. Prototipo de sistema robotizado para osteotomías faciales desarrollado conjuntamente con el Hospital Vall d'Hebrón y la Universtat Politécnica de Catalunya.

Figure 2. Prototype robotic system for facial osteotomy developed jointly by Vall Hospital d'Hebrón and Universtat Politécnica de Catalunya.

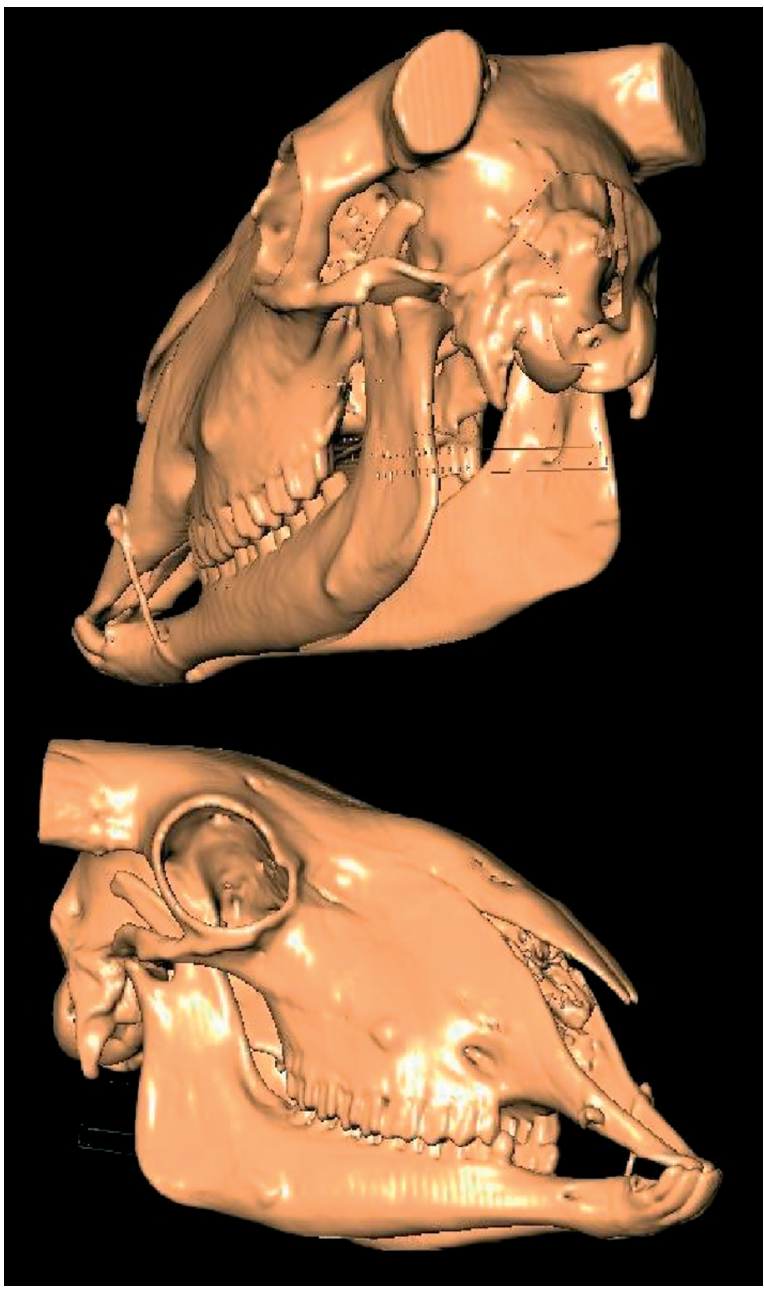

Figura 3. Modelo volumétrico generado por el sistema.

Figure 3. Volumetric model generated by system.

\section{Robots in oral and maxillofacial surgery}

Only anecdotal experiences exist with robots in oral and maxillofacial surgery. There have been few experiences in our specialty, most of which have centered on surgery of the bone because it is the tissue most accurately visualized by CAT scan. Most published prototypes have not been used in operating rooms with real patients. ${ }^{18}$ One reason for this is that most commercial systems have been developed for endoscopic surgery, which still has only limited applications in our specialty. The cost of the equipment and our limited catalogue of minimally invasive procedures make it difficult to develop this technology. The introduction of endoscopy in facial traumatology, temporomandibular joint and salivary gland procedures is opening up possibilities for using these tools in our field. At the AAOMS Research Summit held in Chicago in 2005, the AAOMS cited robotic technologies, minimally invasive surgery, nanotechnology, and miniaturization as emergent technologies with potential to be used more in our specialty. In Europe there is much interest in this field, although investigative efforts have concentrated on navigation techniques. Prototypes of robotic maxillofacial surgery have been developed in Germany, Austria, and France. ${ }^{17}$

\section{Experiences in Spain}

In Spain, the group of Vall d'Hebrón Hospital and Universitat Politècnica de Catalunya designed a robotic system for osteotomy. The system was equipped with a robotic arm that controlled the movements of a handpiece with a shank or Lindeman drill (Fig. 2). 
ritmos matemáticos el sistema identifica las dianas y por triangulación determina la posición en el espacio del modelo real. Conocida la posición de la cabeza real, el sistema orienta el modelo virtual que vemos en pantalla. Al girar la cabeza de nuestro paciente, el modelo en pantalla gira al mismo tiempo.

El tercer módulo es el de planificación. Permite mover, girar, ampliar y visualizar nuestro modelo virtual. Sobre el podemos diseñar la osteotomía que queremos efectuar o bien proteger estructuras como vasos o nervios para no lesionarlos si somos nosotros quienes llevaremos la herramienta de corte (Fig. 4).

Por último, el cuarto módulo es el de ejecución. Es la parte del sistema que gobierna el robot, integrando la información de imagen, coordenadas y de planificación.

La ejecución de la osteotomía puede efectuarse en tres formas:

1. Ejecución automática: el robot efectúa el procedimiento de forma autónoma, del mismo modo que actúan los robots de corte en la industria.

2. Ejecución semi-automática: el cirujano efectúa el avance del corte, pero el robot limita un plano de deslizamiento, actuando como si trabajásemos sobre una regla.

3. Ejecución tutelada: en la planificación se delimita un volumen fuera del cual la herramienta de corte no puede salir. Podemos trabajar manualmente dentro de este espacio planificado.

Un prototipo similar denominado Surgicobot, aunque sin sistema de seguimiento de la posición del paciente en tiempo real, fue desarrollado en Amiens (Francia). ${ }^{17}$

Otro prototipos emplean distintos sistemas de posicionamiento, por infrarrojos, ondas hertzianas, etc.

\section{Conclusiones}

La tecnología robótica ha despertado interés en los cirujanos desde hace décadas. A pesar de su exitosa incorporación a los procesos industriales no ha ocurrido lo mismo en cirugía y en las ciencias de la salud en general. Cuestiones como los costes, el entorno del quirófano y las características de variabilidad de los seres vivos y sus tejidos dificultan la incorporación de estas máquinas a la actividad quirúrgica.

El desarrollo de nuevas tecnologías robóticas con dispositivos miniaturizados, que puedan trabajar de forma cooperativa, con percepción físico-química y espacial del entorno auguran nuevas expectativas que con el tiempo se deberán confirmar.

Nuestro país se encuentra en una posición destacada en la investigación y desarrollo de estas tecnologías, a pesar del handicap que supone la falta crónica de un soporte industrial y de capital-riesgo.
The system had four different modules. The first module is the imaging module, which captures and manipulates the computed tomography image, generating a three-dimensional model from tomographic DICOM files (Fig. 3). The second module identifies coordinates. It coordinates the spatial position of the virtual model with reality in real time. It uses computerized vision technology. The real patient has targets adhered to the surface and the computer sees the real object using three cameras. The system identifies the targets with mathematical algorithms and determines the spatial position of the real model by triangulation. The system captures the position of the real head and orients the virtual model visible on screen. As the patient's head turns, the on-screen model turns at the same time.

The third module is used for planning. It allows us to move, turn, enlarge, and visualize our virtual model. We can design the osteotomy that we want to perform on the model, or plan how to protect structures like vessels or nerves to avoid injury when using the cutting tool (Fig. 4).

Finally, the fourth module is execution. This part of the system governs the robot, integrating imaging, coordinates and planning information.

Osteotomies can be executed in three ways:

1. Automatic execution: the robot performs the procedure independently, just like cutting robots work in industrial applications.

2. Semiautomatic execution: the surgeon guides cutting, but the robot defines the plane along which cutting proceeds, acting as a guide for cutting.

3. Guided execution: a volume is defined during planning and the cutting tool cannot proceed beyond this space. We can work manually in this planned space.

A similar prototype without a real-time patient positioning system, called Surgicobot, was developed in Amiens (France)..$^{17}$

Other prototypes use different positioning systems, e.g., infrared, hertzian waves, and others.

\section{Conclusions}

Robotic technology has interested surgeons for decades. Although robotics has been successfully incorporated in industrial processes, this has not been the case in surgery and general health sciences. Questions like cost, the operating room setting, and variability of the characteristics of living 


\section{Bibliografía}

1. Diodato MD, Prosad SM, Klingensmith ME, Damiano RJ. Robotics in surgery. Curr Probl Surg 2004;41:752-810.

2. Nilo D, Dicks J, Linsen MAM, Cuesta MA, Gracia C, Rauwerda JA, Wisselink W. Robot-assisted laparoscopic aortobifemoral bypass for aortoiliac occlusive disease: early clinical experience. Eur / Vasc Endovasc Surg 2005;29:586-90.

3. Varkarakis IM, Bais-Bahrami S, Kavoussi LR, Stoianovici D. Robotic surgery and telesurgery in urology. Urology 2005;65:840-6.

4. Wurm J, Steinhart H, Bumm K, Vogele M, Nimsky C, Iro H. A novel robot system fot fully automated paranasal sinus surgery. Internacional Congress Series 2003;1256:633-8.

5. McBeth PB, Louw DF, Rizan PR, Sutherland GR. Robotics in neurosurgery. Am J Surg 2004;188(Sppl to October 2004)68S-75S.

6. Harrell, AG, Heniford T: Minimally invasive abdominal surgery: lux et veritas past, present and future. Am / Surg 2005;190:239-43.

7. Camarillo DB, Krummel TM, Salisbury JK. Robotic technology in surgery: past, present and future. Am / Surg 2004;188(supp october 2004):2S-15S.

8. Corp. W, Marmulla R, Raczkowsky J, Mühling J, Hassfeld S. Robots in the operating theatre-chances and challenges. Int J Oral Maxillofac Surg 2004;33:72132.

9. Nageotte F, de Mathelin M, Doignon C, Soler L, Leroy J, Marescaux J. Computer-aided suturing in laparoscopic surgery. Internacional Congress Series 2004; 1268:781-6.

10. Maniar HS, Council ML, Prasad SM, Phil M, Prasad SM, Chu C, Damiano RJ. Comparison of skill training with robotic systems and tradicional endoscopy: implications on training and adoption. / Surg Res 2005;125:23-9.

11. Daumas B, Xu WL, Bronlund J. Jaw mechanism modeling and simulation. Mechanism and Machine Theory 2005;40:821-33.

12. Wang L, Sadler JP, Breeding LC. A robotic system for testing dental implants. Mechanism and Machine Theory 1998;33:p583-97.

13. Wang DA, Bello F, Darzi A. Augmented reality provision in robotically assisted minimally invasive surgery. Internacional Congress Series 2004;1268:527-32.

14. Hassfeld S, Mühling J. Computer assisted oral and maxillofacial surgery - a review and an assessment of technology. Int J Oral Maxillofac Surg 2001;30:2-13.

15. Hausamen JE. The scientific development of maxillofacial surgery in the 20th century and an outlook into the future. / Cranio Maxillofac Surg 2001;29:2-21.

16. Troulis MJ, Ward BB, Zuniga JA. Emergin Technologies: Findings of the 2005 AAOMS Research Summit. J Oral Maxillofac Surg 2005;63:1436-42.

17. Taha F, Gravez P, d'Hauthuille C, Bonneau E, Devauchelle B. Surgicobot: surgical gesture assistance cobot for maxillo-facial interventions (abstract). J Cranio Maxillofac Surg 2004;32(Supp 1):83.

18. Ayav A, Bresler L, Brunaud L, Boissel P. Early results of one-year robotic surgery using the Da Vinci system to perform advanced laparoscopic procedures. / Gastrointest Surg 2004;8:720-6. beings and their tissues make it difficult to incorporate these machines into surgical activity.

The development of new robotic technologies, including miniaturized devices that can work cooperatively and have physicochemical and spatial perception of their surroundings, generates new expectations that will be assessed with time.

Spain occupies a noteworthy position in robotics research and development, despite a chronic lack of industrial support and venture capital. 